\title{
The Role of Higher Education in Promoting Social Mobility in Indonesia
}

\author{
Muhammad Husni Arifin \\ Departement of Sociology Universitas Terbuka Indonesia
}

\begin{abstract}
This paper explains the link between higher education and social mobility in Indonesia. There are several theoretical frameworks talking about the link between higher education and social mobility and the relevant theory of them is Raymond Boudon's Inequality of Educational Opportunity (IEO) and Inequality of Social Opportunity (ISO). The results reveal that the link between higher education and social mobility in Indonesia is influenced by other factors: inequality of social-economy and geography and cultural disparities. Furthermore, the more decreasing inequality in the society, the more people can go to higher education and in turn will promote upward social mobility.
\end{abstract}

Keywords: higher education, social mobility, educational opportunity, social opportunity

\section{Introduction}

This paper is written related to the fact that there is a paucity in the study of the role of higher education attainment toward upward social mobility in Indonesia. According to many studies, the study of social mobility is very important to learn the accessibility of a community toward education and the inequality in the education (Mok 2016). Moreover, social mobility is correlated to social origins and social reproduction. Student's social origins and social reproduction are a pivotal mean to know factors influencing students' persistence and performance in the higher education. Prior studies on student persistence and performance stated that student's social origins are a determinant factor to determine student's decision to persisting and completing study (Kember 1989, 1995, 2007; Sweet 1986; Tinto 1993).

When the globalisation and the evolution of the knowledge-based economy got fully underway, the function and characteristics of education in the world are changing dramatically (Burbules \& Torres 2000; Crossley 2000). In recent years, higher education credentials become a pivotal instrument in the global competitiveness and then made many countries in the world increasing number of higher education and professional institutions in their respective countries. However, the rapid expansion of higher education is not correlated positively with employment and social mobility. For intances, around $40-50 \%$ of college graduates in the USA are doing sub-graduate work; about $52 \%$ of four year college graduates are in job that match their skills, whereas $48 \%$ are overqualified for their current jobs (Vedder, Denhart, dan Robe 2013). In the same way, Green and Mok (2013) found the growing number of unemployed college graduates in Europe and Asia.

Therefore, there are pros and cons regarding the link between educational attainment and social mobility. Prior empirical studies, particularly that have used human capital theory, highlighted a positive correlation between the level of education and earnings. The youth people who completed and hold higher education credentials usually have higher earnings and more opportunity for upward mobility. Therefore, in this case, higher education attainment is an important determinant of social mobility (Checchi 2004; Becker 1993; Psacharopoulos, 1994; Psacharopoulos dan Patrinos, 2004). Whereas, some scholars believe the opposite perspective that the most significant determinants of income and social mobility are not education-related factors (Young 1990). According to these scholars, some prior studies showed that family background significantly affects educational achievement and graduates' employment in the labour market (Brown et al. 2001; Dale 2015; Coleman et al. 1966). Therefore, obtaining a higher education credential is no longer guarantee of employment, higher earnings, or most importantly, upward social mobility.

Based on these pros and cons perspectives, the role of higher education in social mobility is context-bounded and needs comparative research. Hence, this paper will examine the effect of higher education attainment on upward social mobility in Indonesia. 


\section{Research Method}

This study used the secondary data as a primary source including the relevant prior studies, statistical data, journal articles, and other sources. Furthermore, these data were analised descriptively in order to know the role of higher education attainment toward upward social mobility in Indonesia.

\section{Higher Education, Educational Opportunity, and Social Mobility}

The role of educational institutions, particularly schools and higher education, become more important since the schools have taken on functions formerly performed by the church, the family, and a number of other institutions. Starting in 1950s, higher education serves as a vehicle of mobility for masses of people and becomes a mandatory stage in the trajectories of upward mobility (Burlutskaia 2014).

In relation to the role of higher education, John Goldthorpe (2002) stated that higher education attainment can develop a merit-based system. This a merit-based system is expected to replace social class in determining economic earnings. Moreover, Goldthorpe (2002) revealed that higher education attainment functions also as a filter for parents to keep parents' economic position by passing straight through to their children.

According to Gholthorpe (2002), a less class-based society needs several requirements: 1) the link between individuals' social origins and their schooling must incresingly reflect only their ability; 2) the link between their schooling and their eventual employment must be strengthened by qualifications acquired through education; 3 ) the link between schooling and emplyment must become constant for individual of differing social origins.

However, the link between higher education and upward social mobility is frequently mediated by economic position or family earnings. For instances, the children from wealthy family tend to have meritokratic characteristics, such as ability, motivation, and preparedness, comparing to poor family. Therefore, the children having the meritocratic characteristics tend to have more opportunity to get upward social mobility (Shapiro \& Willen 2005). From this case, it can be said that there is a link among social economic status, meritocratic traits, and upward social mobility.

Furthermore, in relation to the link among educational opportunity, social origins, and social mobility, Raymond Boudon (1974) proposes two concepts of 'inequality of educational opportunity' (IEO) dan 'inequality of social opportunity' (ISO). IEO refers to differences in educational attainment according to social background. Whereas ISO is defined as differences in achieved social status according to social background.

The model of social opportunity developed by Boudon (1964) includes two components: 1) a model of changing IEO under conditions of educational expansion, and 2) a model of ISO under conditions in which the supply of educated individuals grows more rapidly than the availability of social positions. Therefore, the Boudon model needs a meritocratic society to apply the model in which the highest social positions tend to go to those with the highest levels of education.

Moreover, the most crucial element of the IEO component is Boudon's distinction between the primary and secondary effects of social stratification on educational inequality. In this case, the primary effects refer to those expressed through the association between childrens's social backgrounds and their educational performance. Meanwhile, the secondary effects are expressed through the educational choices made by children from differing social backgrounds but with similar levels of performance. From this explanation, it can be stated that Boudon explicitly differentiates between cultural (primary effects) and positional (secondary) effects. (Boudon 1974; Jackson \& Jonsson 2013).

In relation to IEO and ISO, there are four axioms to identify Boudon's IEO and two axioms to define ISO. The subsequent axioms (E1-E4) explain the method in which primary and secondary effects of social stratification combine to produce socially differentiated educational outcomes for a group of students (Thompson and Simmons 2013).

E1: the society is stratified, and primary effects of stratification exist in which underlying academic acability is differentiated by social class from an early age. These primary effects are persistent; that is, the academic aptitude of an individual does not change over time.

E2: the curriculum available to young people is differentiated for a substantial proportion of an educational career. Some routes offer progression to the highest levels of academic attainment, whilst others do not. At certain transition points, students must choose whether to continue with the higher curriculum. Once having left this curriculum, students are unlikely to return to it. 
E3: at any transition, secondary effects of social stratification operate, so that the probability of a particular individual continuing with the higher curriculum is an increasing function of social status as well as academic aptitude.

E4: the society is in a state of educational expansion. The probabilities of continuing with the higher curriculum are increasing with time, although not necessarily uniformly for all social groups.

Whereas, two assumptions as a foundation in the ISO generating component are as follows:

S1: the social structure, in terms of the number of social positions available at each level, changes considerably less rapidly over time than the educational structure.

S2: an individual's achieved status depends on four independent variables: social background; educational attainment; social structure; and educational structure, in terms of the number of people reaching each level of educational attainment.

Therefore, despite many factors influencing social mobility, the nature and form of education plays an important role in individual social achievement. In this case, Boudon's model highlights that greater differentiation within education increases inequality of attainment, over and above that which can be attributed to socio-cultural influences on academic aptitude (Thompson and Simmons 2013).

\section{Higher Education in Indonesia from the Colonial Era to Post-Colonial Era}

The development of higher education in Indonesia was closely related to prior colonialism (1500S - 1942). In the colonial era, the Dutch established the first formal and official universities in Java starting at the end of the eighteenth century. The reason behind these establishment was to fulfill the shortage of Dutch experts, especially during World War One. Some universities established by the Dutch were the medical school and law school in Jakarta, the engineering institute in Bandung, and the agriculture center in Bogor. In that time, Dutch was the exclusive language of instruction and served as an effective means of selection of male nobles across the thin numbers of high school graduates (Logli 2016; Idrus 1999).

The student profiles in the universities reflected the colonial hierarchy, with the Dutch at the top and the indicenous people at the bottom. However, the number of Indonesian students increased steadily year by year and in 1938, their number rose to 200 out of the total 1000 students (Buchori and Malik 2004; Cummings and Kasenda 1989). Beyond the numbers, colonial universities were actually arenas of social and cultural conflict. On one side, colonial universities were a pivotal mean to get opportunity to climb the colonial hierarchy towards a higher social status and better jobs. On the other side, the Indonesian student were worried about lossing of their original identities and traditions due to Dutch education (Alisjahbana 1966).

Moreover, the establishment of colonial universities in Indonesia had opened the pandora's box by creating the elite intelletual groups of colonial universities graduates that in turn protested and rejected the colonialism. Those groups also became leaders in endorsing nationalism and eradicating colonialism in Indonesia (Buchori \& Malik 2004; Cummings \& Kasenda 1989).

In the post-colonial era, after getting independence from Japan, the delopment of higher education system was much influenced by political situations. In 1945, the first state Islamic university was established with the name Universitas Islam Indonesia. Whereas, Universitas Gajah Mada was the first Indonesian secular university with no colonial legacy established in 1949. In 1961, Indonesian Government enacted the 1961 Law No 22 on Higher Education and by this law, the government prescribed the establishment of at least one public university in each province of Indonesia to expand accessibility and equal opportunity for all citizen (Buchori and Malik 2004; Mason, Arnove and Sutton 2001; Nizam 2006).

The main effect of the 1961 Law No. 22 is the fast growing number of private higher education institutions in Indonesia. In 1980, the number of private higher education was above 1,000 institutions for all regions in Indonesia. However, private higher education institutions in Indonesia has a pivotal role in opening access to higher education and increase participation for those people who can not attend in the state higher education. Finally in 1990, the number of graduates of private higher education institutions has exceeded the number of graduates of state higher education (Logli 2016; Kristiansen \&Pratikno 2006).

The growing number of private higher education institutions unveil other problems, the quality of learning process and graduates. In the meantime, lack of autonomy becomes another problem to encounter by the institutions. Consequently, higher education in the Soeharto era tend to be less innovative due to merely birocratic and sentralistic. 
Therefore, Indonesian government through the ministry of higher education set up the quality standard for both graduates of higher education and learning process in higher education.

In the post-Soeharto era, there is a shifting in the higher education system that the Indonesian government provides more autonomy in finance dan institutional development in order to endorse more Indonesia universities becoming a world class university. This changing system was enacted initially by Law of Education Agency on 17th December 2008 (Brojonegoro 2012; DJKN 2013).

However, the enactment of the Law of Educational Agency has impacted on commercialisation of higher education. This situation has brought to inequality of educational opportunity. Later, the Law of Education Agency has been cancelled by the Supreme Court due to against the highest law of 1945 (Purbayanto 2012; Prasetya 2005; Basit 2017; Subhan 2012; DJKN 2013). Therefore, the Indonesian Government replaced the Law of Education Agency by enacting the Law No. 12 year 2012 on Higher Education.

\section{The Size of Students and Higher Education in Indonesia}

Indonesian government has established a state university in every regions throughout Indonesia. However, the number of those universities were not able to absorb the high number of people who want to learn at higher education level. Due to the out of number of people to study at the university level, Indonesian government invited public participation to establish private universities. In 2016, the number of state and private universities in Indonesia reached 4312 institutions (diagram 1). Comparing to China, the number of university in Indonesia is higher than in China (2000 universities and 6 million students) but with fewer students (Mok 2016).

Diagram 1. Number of Public and Private Universities in Indonesia

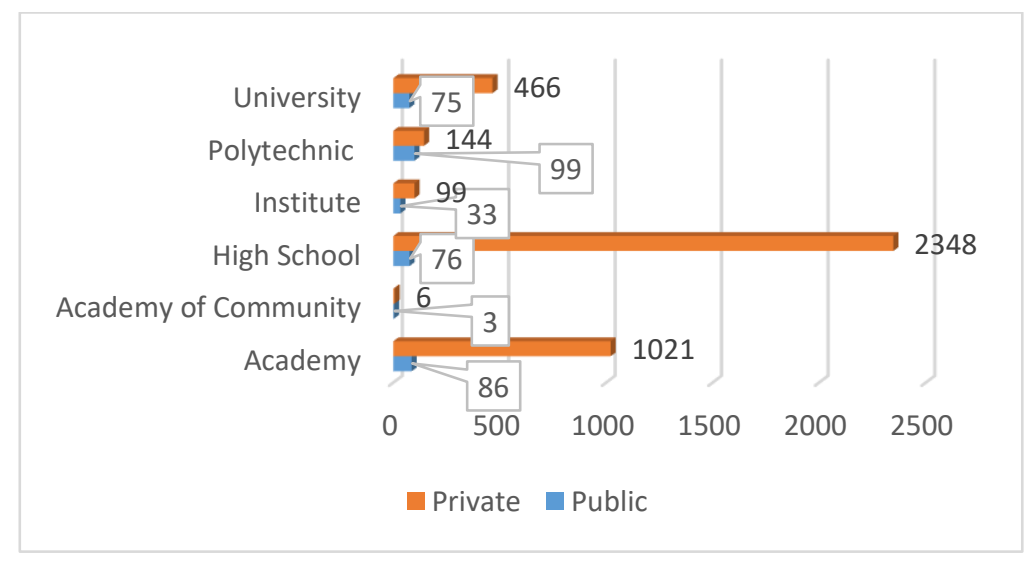

Source: http://kelembagaan.ristekdikti.go.id/index.php/statistik-5/

In 2016, the number of students at public universities reached 1,979,584 students enrolling in diversing disciplines (diagram 2). Among those disciplines, most students enrolled in education $(697,739)$ and then followed by social sciences around 312,525 students (Ristekdikti, 2017). The reason behind the high number of students selecting education due to the shifting of education institutes into a university and offers more course programmes to students. 
Diagram 2. Number of Students according course programme at state universities

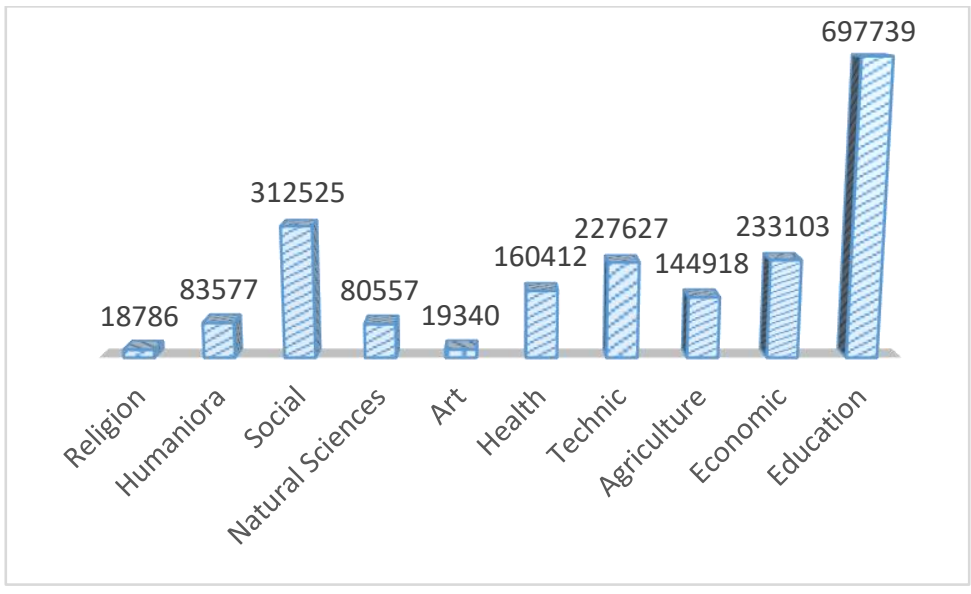

Source: http://kelembagaan.ristekdikti.go.id/index.php/statistik-5/

Meanwhile, the number of all students (2,966,686 students) from private universities (4,084 universities) is double than number of students at state universities. Diagram 3 shows that most students at private universities selected economics, engineering, education, and social sciences. These selections are probably caused by the high demand of those graduates in labour market.

Diagram 3. Number of students at private univesities according to course programmes

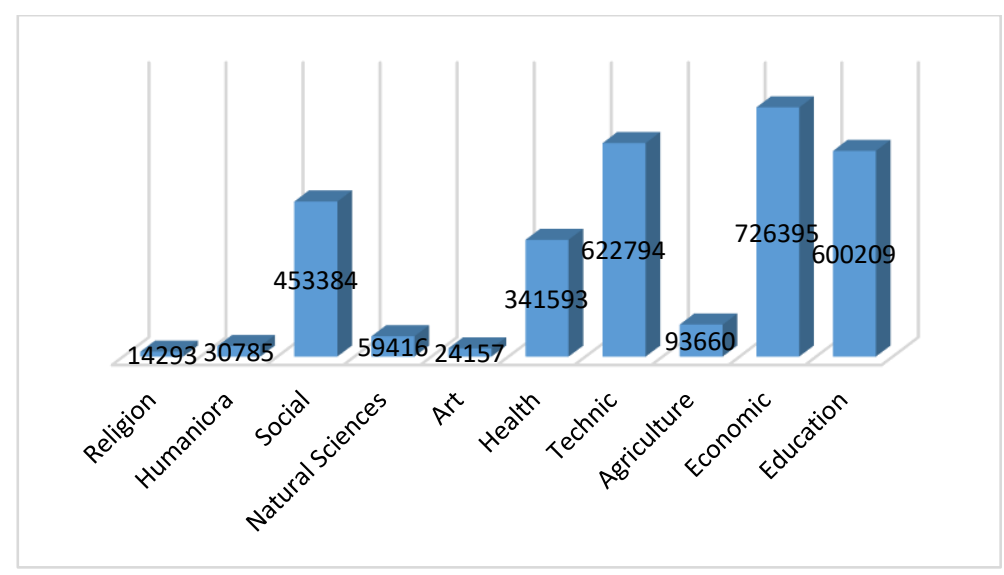

Source: http://forlap.dikti.go.id/mahasiswa/homegraphbidang

Meanwhile, according to gender, female students more interested in studying at higher education than male students (diagram 4). This data shows a cultural shifting in society that patriarchy is starting to fade and providing female people social opportunity to get higher education. 
Diagram 4. Number of students according to gender

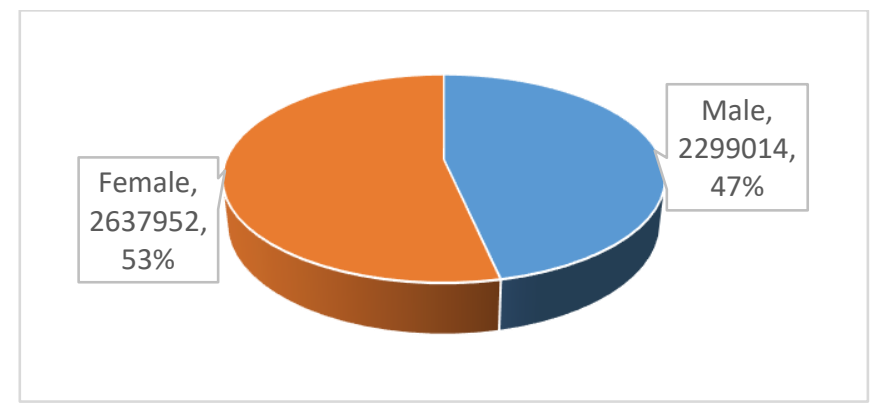

Source: http://forlap.dikti.go.id/mahasiswa/homegraphjk

\section{The Effect of Higher Education Attainment on Social Mobility in Indonesia}

Social mobility in society is influenced by many factors and education is the most significant factor in promoting social mobility (lanneli \& Peterson 2007; Haveman \& Smeeding 2006). Moreover, several studies showed that the positive link between educational level and salary (Mok 2015).

However, many studies of social mobility were missed to explain the role of social inequality in the society. Therefore, facts of domination and oppression in the society should be investigated in the studies. Other studies founded that accessibility to higher education is not only determined by education but also family background (Gao 2011; Brown, Lauder \& Ashton 2011). Moreover, the emergence of globalisation also changes the predictors of social mobility in which the ownership of certificate of university level has not direct effect on easyness to get job, income, and particularly upward mobility.

In terms of accessibility, rough participation rate at the university level around $20,89 \%$ in 2015 even this rate is lower than rate in 2013 and 2014. Moreover, rough participation rate at the university level is lower than elementary school level (109,94\%), junior high school (90,63\%) and senior high school (77,39\%) (BPS 2017).

There are several barriers to go to higher education, such as social and economics status, and cultural and geography disparities. However, the most determinant barries of those factors are social and economics status (Moeliodihardjo 2013). The link between educational opportunity and social and economics status might be reflected in rough participation rate of education in Indonesia. Table 1 shows that the lowest particpation rate is higher education due to socio-economic factors. In this case, the lower socio-economic status they have, the lower access the get to study at higher education (World Bank 2014).

Tabel 1. Number of Rough Participation Rate according to Education Background

\section{In Percent}

Post-Secondary School

Senior High School

Junior High School

Elementary

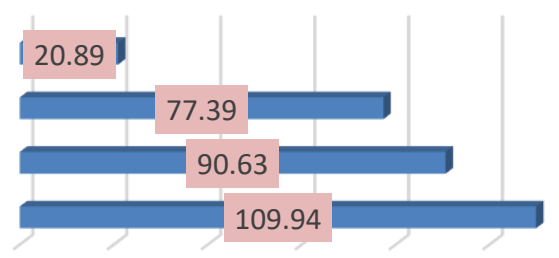

$\begin{array}{lllllll}0 & 20 & 40 & 60 & 80 & 100 & 120\end{array}$ 
Source: BPS, 2017

\section{CULTURAL AND GEOGRAPHICAL DISPARITIES}

Geographical disparity refers to the lack of social and economics infrastructures in underdeveloped regions and remote areas (Moeliodihardjo 2010). The emergence of geographical disparity in Indonesia has affected many people to get an educational opportunity, particularly access to higher education. This issue might be reflected in providing scholarship of BIDIK MISI by Indonesian Ministry of Higher Education. This scholarship has not reach the poor people living outside Java island and is only focused for people living in Java island. (World Bank 2014). The result of study conducted by World Bank (2014) revealed inequality in educational opportunity between communities living in Java island and other coomunities in Sumatera island. In this context, geographical disparity has influenced educational opportunity between Javanese and nonJavanese.

The long distance from town centre is also a big barrier for people to get access to higher education. The results of the study conducted by the World Bank indicated that almost $58 \%$ students enrolled in higher education institutions come from the lowest social group and reside in rural areas. Furthermore, the lack of high quality of higher education institutions becomes another barrier for rural people in remote areas to have a social opportunity for getting access to higher education.

Meanwhile, cultural disparity describes several factors influencing access level to higher education, such as ethnicity, language, and gender. Indonesia has almost 300 thousands etnic groups and more than 700 local languages. Therefore, the use of Indonesia language in schools becomes a barrier for children to complete their studies. According to World Bank (2014), the number of dropout students who did not speak Indonesian language is higher than students who speak Indonesian language. Furthermore, a gender disparity is also becoming a barrier for marginal people in accessing higher education. This barrier comes up due to hegemony of patriarchy in society.

Therefore, there are multiple barriers for the lowest social groups in getting social and educational opportunities in which those barriers are not only social economic status but also including geography and cultural disparities.

\section{Conclusion}

The discussion on social mobility in the society is commonly used as a mean to legitimize or hidden the fact of social inequality. The gap between the rich and the poor is frequently presented as a common fact. However, there are numerous facts behind these phenomena that inequality of educational opportunity may influence one's accessibility to higher education as a mean to get an upward social mobility.

Analysis toward social mobility in Indonesia indicated that higher education attainment is a pivotal factor in promoting upward social mobility. However, there are many barriers for Indonesian people to get access to higher education due to social inequality. Therefore, in this case, the Boudon's model of Inequality of Educational Opportunity (IEO) and Inequality of Social Opportunity (ISO) is quitely relevant for analysing social mobility in Indonesia.

Moreover, the relationship between higher education and upward social mobility in Indonesia is mediated by inequalities in the society, such as social-economics inequalities, geography, and cultural inequality. Therefore, it can be said that the more decreasing inequality in the society, the more people can go to higher education and in turn will promote upward social mobility.

\section{References}

[1] Alisjahbana, S. 1966. Indonesia: Social and Cultural Revolution. Kuala Lumpur, Malaysia: Oxford University Press.

[2] Basit, A. 2017."Perguruan Tinggi Neger Berbadan Hukum (PTN-BH)". Diakses 07 Februari 2017 (http://www.academia.edu/23955310/PERGURUAN_TINGGI_NEGERI_BERBADAN_HUKUM_PTNBH_ANTARA).

[3] Becker, G. S. 1993. Human Capital: A Theoretical and Empirical Analysis, with special Reference to Education. 3rd ed. Chicago, IL: The University of ChicagoPress. 
[4] Boudon, R. 1974. Education, Opportunity and Social Inequality: ChangingProspects in Western Society. London: John Wiley.

[5] Boudon, R. 1976. "Comment on Hauser's review of Education, Opportunity and Social Inequality." American Journal of Sociology 81 (5): 1175-1187.

[6] Brojonegoro, S. S. 2012. "Landasan implementasi perguruan tinggi sebagai badan hukum milik negara." Dalam Otonomi Perguruan Tinggi Suatu Keniscayaan, diedit oleh Sulistyowati Irianto. Jakarta: Yayasan Pustaka Obor Indonesia.

[7] Brown, P., H. Lauder, and D. Ashton. 2011. The Global Auction: The Broken Promises of Education, Jobs, and Incomes. New York: Oxford University Press.

[8] Burbules, N. C., and C. A. Torres. 2000. Globalization and Education: CriticalPerspectives. New York: Routledge.

[9] Buchori, M. dan A. Malik. 2004. "The Evolution of Higher Education in Indonesia". Pp. 249-277 inAsian Universities: Historical Perspectives and Contemporary Challenges, edited by Altbach, P. and T. Umakoshi. Baltimore, MD: Johns Hopkins University Press.

[10] Crossley, M. 2000. "Bridging Cultures and Traditions in the Reconceptualisation ofComparative and International Education." Comparative Education 36 (3): 319-332.

[11] Checchi, D. 2006. The Economics of Education: Human Capital, Family Backgroundand Inequality. New York: Cambridge University Press.

[12] Coleman, J. S., et al. 1966. Equality of Educational Opportunity. 3rd ed. Salem,OR: New Hampshire.

[13] Cummings, W. and S. Kasenda. 1989. "The Origin of Modern Indonesian Higher Education". Pp 143-166 in From Dependence to Autonomy: The Development of Asian Universities, edited by Altbach, P. \& V. Selvaratnam. Boston, MA: Kluwer Academic.

[14] Dale, R. 2015. "Employability and Mobility in the Valorization of Higher EducationQualifications." Paper presented at the International Symposium on Globalization,Changing Labout Market and Social Mobility: Challenges for Educationand Urban Governance, 20 January 2015, Hong Kong Institute of Education.

[15] DJKN (Direktorat Jenderal Kekayaan Negara). 2013."Perguruan Tinggi Eks BHMN Lahir Kembali dengan Casing Baru." Diakses 07 Februari 2017(https://www.djkn.kemenkeu.go.id/artikel/detail/perguruan-tinggi-eksbhmn-lahir-kembali-dengan-casing-baru).

[16] Gao, L. 2011. Impacts of Cultural Capital on Student College Choice in China. Lanham, MD: Lexington Books.

[17] Green, A., and K. H. Mok. 2013. "Expansion of Higher Education, Gradaute Employment and Social Mobility: An Asia and Europe Dialogue." Paper presented at the 2013 Hong Kong Educational Research Association Annual Conference, February 2013, Hong Kong Institute of Education

[18] Haveman, R and T. Smeeding. 2006. "The Role of Higher Education in Social Mobility." The Future of Children16 (2): $125-150$.

[19] lanneli, C and Paterson L. 2007. "Education and social mobility in Scotland."Research in Social Stratification and Mobility, 25, $219-232$.

[20] Idrus, I. 1999. "Towards quality higher education in Indonesia". Quality Assurance in Education, Vol. 7 Iss 3 pp. $134-141$

[21] Jackson, M., and J. Jonsson. 2013. "Inequality of Educational Opportunity AcrossCountries." In Determined to Succeed? Performance versus Choice inEducational Attainment, edited by M. Jackson. Stanford, CA: StanfordUniversity Press. 
[22] Logli, C. 2016."Higher Education in Indonesia: Contemporary Challenges in Governance, Access, and Quality." InThe Palgrave Handbook of Asia Pacific Higher Education, edited by C. S. Collins, et al.Santa Barbara USA: Palgrave Macmillan US

[23] Mason, T., R. Arnove, and M. Sutton. 2001. "Credits, Curriculum, and Control in Higher

[24] Education: Cross-national Perspectives." Higher Education, No. 42 (1):107-137.

[25] Mok, Ka Hok. 2016. "Massification of higher education, graduate employmentand social mobility in the Greater China region."British Journal of Sociology of Education 37 (1):51-71. DOI: 10.1080/01425692.2015.1111751

[26] Moeliodihardjo, B.Y. 2013. Equity and Access in Higher Education. World Bank: Jakarta

[27] Nizam. 2006. "Indonesia." In Higher Education in South-East Asia, ed. UNESCO. Bangkok, Thailand: UNESCO. 35-68.

[28] Psacharopoulos, G. 1994. "Returns to Investment in Education: A Global Update."World Development 22 (9): 1325-1343.

[29] Psacharopoulos, G., and H. A. Patrinos. 2004. "Returns to Investment in Education:A Further Update." Education Economics 12 (2): 111-134.

[30] Vedder, R., C. Denhart, \& J. Robe. 2013. "Why Are Recent College GraduatesUnderemployed? University Enrollments and Labor-Market Realities." Centerfor College Affordability and Productivity (NJ1). Retrieved February 7, 2017 (http://files.eric.ed.gov/fulltext/ED539373.pdf).

[31] Goldthorpe, J. 2002. "Education-Based Meritocracy: The Barriers to Its Realization," paper presented to the Center for Policy Research, Maxwell School of Syracuse University, retrieved February 8, 2017 (www.cpr.maxwell.syr.edu/seminar/spring05/goldthorpe.pdf)

[32] Shapiro, J. and P. Willen. 2005. "Educational Opportunity and Income Inequality," Journal of Public Economics 89: $841-70$.

[33] Thompson, R \&R. Simmons. 2013."Social mobility and post-compulsory education: revisiting Boudon's model of social opportunity". British Journal of Sociology of Education 34 (5-6):744-765.

[34] Prasetya Online. 2005."Status BHMN Tak Ada Landasan Hukum Jelas." diakses 07/02/2017 (http://prasetya.ub.ac.id/berita/Status-BHMN-Tak-Ada-Landasan-Hukum-Jelas-9779-id.html).

[35] Purbayanto, Ari. 2012."Ke Mana Arah Perguruan Tinggi BHMN Pasca UU BHP?"Dalam Otonomi Perguruan Tinggi Suatu Keniscayaan, disunting oleh Sulistyowati Irianto. Jakarta: Yayasan Pustaka Obor Indonesia.

[36] Subhan, M. H. 2012."Kajian Hukum atas Implikasi Putusan MK tentang Pembatalan UU BHP terhadap Eksistensi PTN BHMN." Dalam Otonomi Perguruan Tinggi Suatu Keniscayaan, disunting oleh Sulistyowati Irianto. Jakarta: Yayasan Pustaka Obor Indonesia.

[37] World Bank. 2014. "Mendorong Pemerataan Pendidikan Tinggi: Policy Brief." Washington, DC : World Bank Group. Diakses 2/2/2017 (http://documents.worldbank.org) 